\title{
Disposable electrochemical DNA biosensor for environmental monitoring of toxicant 2-aminoanthracene in the presence of chlorine in real samples
}

\author{
R MOTAGHED MAZHABI ${ }^{\mathrm{a}, *}$ and M ARVAND ${ }^{\mathrm{b}, *}$ \\ ${ }^{a}$ Department of Chemistry, Islamic Azad University, Arak Branch, Arak, Iran \\ ${ }^{b}$ Department of Chemistry, Faculty of Science, University of Guilan, Namjoo Street, P.O. Box: 1914, \\ Rasht, Iran \\ e-mail: r.motaghed@yahoo.com; arvand@guilan.ac.ir
}

MS received 3 January 2014; revised 18 April 2014; accepted 24 April 2014

\begin{abstract}
A simple procedure for the voltammetric detection of the DNA damage using a disposable electrochemical DNA biosensor is reported. The DNA biosensor is assembled by immobilizing the double stranded calf thymus DNA (dsDNA) on the surface of a disposable carbon screen-printed electrode. The interaction of 2-aminoanthracene (2-AA) with calf thymus dsDNA was studied electrochemically based on the oxidation signals of guanine $(\mathrm{G})$ and adenine $(\mathrm{A})$ by using square wave voltammetry (SWV) at screen printed electrode (SPE). The oxidation signals of the guanine and adenine bases, obtained by a square wave voltammetric scan, were used as analytical signal to detect the DNA damage. The presence of this aromatic amine compound with affinity for nucleic acids was measured by its effect on the guanine and adenine oxidation peaks. The response was obtained in the range of $0.05-20 \mathrm{mg} \mathrm{L}^{-1}$ for 2-AA concentration on dsDNA-modified SPE. This test has been used due to its rapid, easy handling and cost effective responses for the toxicity assessment in real water and bleach solution samples.
\end{abstract}

Keywords. DNA biosensor; 2-aminoanthracene; screen-printed electrode; modified electrode.

\section{Introduction}

DNA plays an important role in the life process, because it bears heritage information and instructs the biological synthesis of proteins and enzymes through the replication and transcription of genetic information in living cells. ${ }^{1}$ After the discovery of electroactivity in nucleic acids at the beginning of the sixties, ${ }^{2}$ many electrochemical approaches have been performed for the analysis of nucleic acids. ${ }^{3}$ There is an increased interest in the application of DNA as biosensors as it is found to have interesting electrical conducting, electrochemical properties and unique hybridization behavior. ${ }^{4}$ Molecules and ions interact with DNA in three significantly different ways: electrostatic, groove-binding and intercalation. These interactions cause changes in the structure of DNA and the base sequence, leading to perturbation of DNA replication. Electrostatic interactions, being usually non-specific, consist of binding along the exterior of the ds-DNA. Groove-binding interactions involve direct interaction of the compound with the edges of the base pairs in the major or minor grooves of dsDNA, extending to fit over many base pairs, and

*For correspondence having very high sequence specificity. ${ }^{5,6}$ Intercalation encompasses inserting planar or nearly planar aromatic ring systems between the base pairs, causing unwinding and separation of base pairs. ${ }^{7}$ Drugs that intercalate into dsDNA have been extensively studied, and the field has been recently reviewed using a variety of techniques. ${ }^{8-17}$ Nucleic acids offer analytical chemists a powerful tool in the recognition and monitoring of many important compounds. ${ }^{5,18}$

Electrochemical biosensors have played an important role in the transition towards point-of-care diagnostic devices. ${ }^{8}$ In recent years, the interest in DNAbased diagnostic tests has been growing. The development of systems allowing DNA detection is motivated by applications in many fields. ${ }^{19}$ The amount of chemicals released into the environment has grown enormously over recent times. These chemicals may undergo biochemical or chemical transformations leading to new compounds of unknown toxicity. Additionally, some of these may be introduced into the trophic chain and can be bioaccumulated in organisms. These facts have created serious concerns regarding their adverse effects on the ecosystem and public health. ${ }^{20}$ For example, several toxicity procedures are currently used for a rapid wastewater toxicity assessment. Numerous biological techniques have been 
developed as toxic detection systems. ${ }^{21-25}$ Toxicity tests using biological responses to measure effects provide valuable information on the significance of chemical contamination. ${ }^{26}$ One of the potentially major applications of a DNA electrochemical biosensor could be the testing of water, food, soil and plant samples for the presence of pathogenic microorganisms and for the presence of analytes (carcinogens, drugs, mutagenic pollutants, etc.) with binding affinities for DNA. ${ }^{27-29}$ The binding of small molecules to DNA and DNA damage in general has been described through the variation of the electrochemical signal of guanine and adenine. ${ }^{28-33}$ Genotoxicity testing is performed to detect DNA damage, or to assay the formation of a DNA adduct and chromosomal damage. It can also be used as a preclinical safety assessment tool to screen newly synthesized drug candidates based on the detection of potential carcinogenicity and heritable mutations based on their responses to genotoxic actions. ${ }^{34}$ Intercalation has been observed with planar aromatic molecules, such as daunomycin, ethidium bromide, acridine dyes, etc. ${ }^{35-37}$

Arylamines are known carcinogens that occur both naturally and in synthetic form. They are employed to manufacture dyes, drugs, inks, rubber antioxidants, plastics and agricultural chemicals. These aromatic amines are also used as curing agents in synthesizing epoxy resins and polyurethanes and are found in road tars and synthetic fuels. 2-Aminoanthracene (2AA) is the benchmark aromatic amine for toxicity studies. It is a model arylamine because relatively, 2-AA is a potent direct-acting carcinogen and induces mutations in eukaryotic and prokaryotic cells. ${ }^{38}$

With this in mind, an electrochemical DNAbiosensor was used to investigate possible DNA damage caused by 2-AA. The electrochemical DNAbiosensor enables us to evaluate and predict DNA interactions and damage by health hazardous compounds, based on their binding to nucleic acids, exploring the use of voltammetric techniques for in situ generation of reactive intermediates, which react with DNA. It is also a complementary tool for the study of biomolecular interaction mechanisms. ${ }^{39}$

In this paper we proposed an electrochemical DNA biosensor as a screening test for environmental toxicant. The disposable electrochemical biosensor was based on the immobilization of dsDNA on the surface of a graphite screen-printed electrode (SPE) and on the use of voltammetry to investigate the electrode surface. The changes in the DNA redox properties (i.e., the oxidation of the guanine and adenine bases) were monitored in order to study the interactions between DNA and the analyte. 2-AA was evaluated in real samples like tap water and bleach solution. The biosensor was highly selective and sensitive for 2-AA determination.

\section{Experimental}

\subsection{Chemicals}

All solutions were prepared using reagent grade chemicals and doubly distilled water was used throughout the work. 2-Aminoanthracene was purchased from Aldrich (Milwaukee, WI). Double-stranded calf thymus DNA, sodium chloride, acetic acid and potassium chloride, dimethyl sulfoxide (DMSO) and ethanol were purchased from Sigma (Steinheim, Germany). Sodium acetate was purchased from Fluka (Buchs, Switzerland). Chlorine bleach $(<5 \%$ chlorine) was bought from local supermarket. Stock solution doublestranded calf thymus DNA (100 $\left.\mathrm{mg} \mathrm{L}^{-1}\right)$ was prepared in distilled water ( $\mathrm{pH} 7.0)$ and kept frozen. More diluted solutions of dsDNA were prepared with acetate buffer solution ( $\mathrm{pH} 4.7$ ) containing $0.1 \mathrm{~mol} \mathrm{~L}^{-1} \mathrm{KCl}$. Stock solution of 2-AA (1000 $\mathrm{mg} \mathrm{L}^{-1}$ ) was prepared by dissolving accurately weighed amount of 2 -AA in $20 \%$ mixture of DMSO/ethanol. The solution was conserved at $4{ }^{\circ} \mathrm{C}$, covered with aluminum foil and left to attain room temperature before use. 2-AA working solutions for voltammetric investigations were prepared by dilution of the stock solution with acetate buffer ( $\mathrm{pH} 4.7)$ containing $0.1 \mathrm{~mol} \mathrm{~L}^{-1} \mathrm{KCl}$.

\subsection{Apparatus}

Electrochemical measurements were performed using a PalmSens handheld potentiostat/galvanostat instrument BV (Palm Instrument BV, Houten, The Netherlands) controlled by means of PSTrace 2.3 program for Windows. The screen-printed electrochemical cells $(1.5 \mathrm{~cm} \times 3.0 \mathrm{~cm})$ consist of a graphite working electrode, a graphite counter electrode and a silver pseudoreference electrode. ${ }^{40}$ The graphite working screenprinted electrode surface is $3 \mathrm{~mm}$ in diameter. Each electrode is disposable.

\subsection{Preparation of DNA biosensor}

The electrode surface was pre-treated by applying a potential of $+1.6 \mathrm{~V}$ for $60 \mathrm{~s}$. The biosensor was assembled by immobilizing calf thymus dsDNA at fixed potential $(+0.5 \mathrm{~V}$ vs. Ag screen-printed pseudoreference electrode, for $120 \mathrm{~s}$ ) onto the screen-printed electrode surface. During the immobilization step, the 
strip was immersed in acetate buffer solution containing $20 \mathrm{mg} \mathrm{L}^{-1}$ of calf thymus dsDNA. Then a washing step was performed by immersion of the biosensor in a clean acetate buffer solution for $30 \mathrm{~s}$, in an open circuit condition. The interaction step was performed just by placing $20 \mu \mathrm{L}$ of the sample onto the surface of the DNA biosensor. After $2 \mathrm{~min}$. the biosensor was washed, immersed in acetate buffer and a square wave voltammetric scan was carried out to evaluate the oxidation of guanine residues on the electrode surface. The area of the guanine peak (around $+1.0 \mathrm{~V}$ vs. Ag screen-printed pseudo reference electrode) was measured. Potentially toxic compounds present in water or wastewater samples were evaluated by changes of the electrochemical signal of guanine. We estimated the DNA modification with the value of the percentage of response decrease $(R \%)$ which is the ratio of the guanine peak area (charge under the oxidation peak of guanine, coulomb) after the interaction with the analyte $\left(\mathrm{GPA}_{\mathrm{s}}\right)$, and the guanine peak area after the interaction with the buffer solution $\left(\mathrm{GPA}_{\mathrm{b}}\right)$ :

$$
R \%=\left[\left(\mathrm{GPA}_{\mathrm{s}} / \mathrm{GPA}_{\mathrm{b}}\right)-1\right] \times 100
$$

The result of the test for one sample can be obtained within $6 \mathrm{~min}$. The supporting electrolyte for the voltammetric experiments and for any step in the biosensor setup was acetate buffer $\left(0.25 \mathrm{~mol} \mathrm{~L}^{-1}, \mathrm{pH} 4.7, \mathrm{KCl}\right.$ $\left.0.1 \mathrm{~mol} \mathrm{~L}^{-1}\right)$. Square wave voltammetry parameters were: frequency $=100 \mathrm{~Hz}$, step potential $=15 \mathrm{mV}$, amplitude $=40 \mathrm{mV}$, potential range $0.2-1.2 \mathrm{~V}$ vs. Ag pseudo reference electrode.

\section{Results and discussion}

\subsection{Biosensor development}

The biosensor test format involves four main steps: the electrochemical conditioning of the electrode surface, the calf thymus dsDNA immobilization, the interaction with the sample solution and the electrode surface interrogation. All the measurements were carried out in acetate buffer. As reported in the literature, ${ }^{41,42}$ the carbon working surface needs to be conditioned before the immobilization of the DNA. The application of high potentials in acidic media (acetate buffer $\mathrm{pH}$ 4.7) seems to increase the hydrophilic properties of the electrode surface through the introduction of oxygenated functionalities, accomplished with an oxidative cleaning. ${ }^{43}$ To pretreat the electrode surface we applied a fixed potential of $+1.6 \mathrm{~V}$ vs. Ag pseudo reference SPE for 1 min., thus increasing the resolution of the analytical signal as reported in figure S1. The DNA immobilization procedure as well as the interaction step with the sample solution was also optimized. Square wave voltammetry was the method used to detect the oxidation peaks of guanine and adenine. It is noticeable that the square wave parameters showed a great influence on the biosensor analytical signal. The DNA signal increased with the frequency up to $100 \mathrm{~Hz}$.

\subsection{Electrochemical behaviour of 2-AA on the SPE}

Square wave voltammetric scan of $25 \mathrm{mg} \mathrm{L}^{-1} 2$-AA and calf thymus dsDNA immobilized onto the electrode surface in acetate buffer solution $(\mathrm{pH}=4.7, \mathrm{KCl} 0.1 \mathrm{~mol}$ $\mathrm{L}^{-1}$ ) on the SPE was performed from 0.2 to $1.5 \mathrm{~V}$ and the results are shown in figure 1 . From figure $1 \mathrm{a}$, it can be seen that two anodic peaks due to the oxidation of guanine and adenine residues in $\mathrm{DNA}^{44,45}$ are observed at around +1.0 and $+1.3 \mathrm{~V}$, respectively, while from figure $1 \mathrm{~b}$ an oxidation peak at $+0.7 \mathrm{~V}$ for 2 -AA can be seen.

\subsection{Interaction of 2-AA with the $A S D N A$ at the modified-SPE using SWV}

The electrochemical interaction between 2-AA and the dsDNA was investigated. It is known that planar condensed aromatic ring systems in 2-AA play a major role in their interaction with DNA, primarily involving stacking interactions. SWV oxidation signals of guanine and adenine at dsDNA-modified SPE, before and after interaction with 2-AA on the electrode surface, are shown in figure 2. Figure 2 a shows the background voltammogram of acetate buffer $(\mathrm{pH} 4.7)$ at the bare SPE. From figure $2 b$ and $2 c$ it can be seen that the oxidation signals of guanine and adenine obtained from

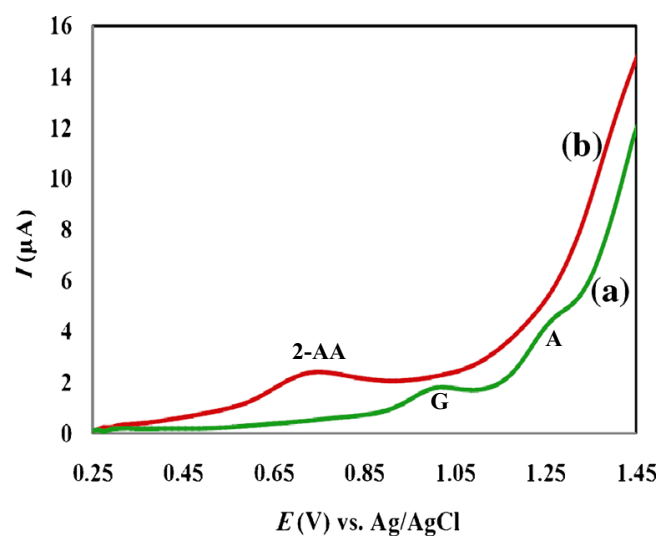

Figure 1. Oxidation of (a) calf thymus dsDNA immobilized onto the electrode surface and (b) 2-AA $\left(25 \mathrm{mg} \mathrm{L}^{-1}\right)$ at a bare SPE into the acetate buffer solution $(\mathrm{pH}=4.7, \mathrm{KCl}$ $0.1 \mathrm{~mol} \mathrm{~L}^{-1}$ ). 


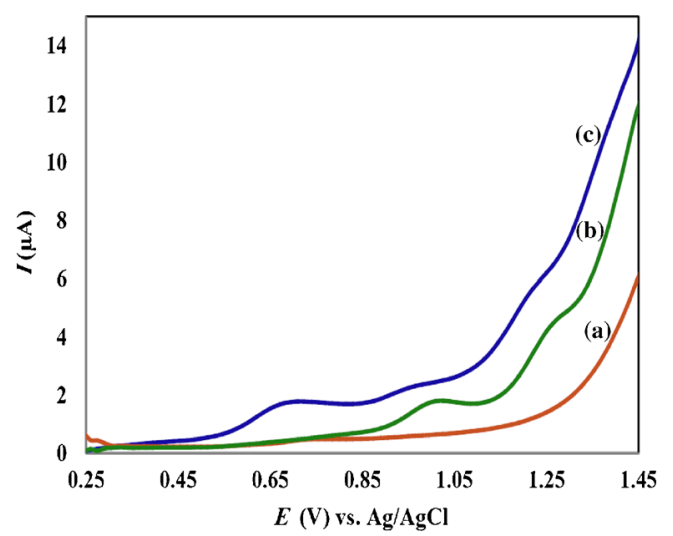

Figure 2. (a) Differential pulse voltammograms of acetate buffer solution $\left(\mathrm{pH}=4.7, \mathrm{KCl} 0.1 \mathrm{~mol} \mathrm{~L}^{-1}\right)$ at a bare SPE (the background signal) (b) Oxidation signals of guanine and adenine obtained from dsDNA-modified electrode (c) Oxidation signals of guanine and adenine obtained from dsDNAmodified electrode after interaction with 2-AA $\left(10 \mathrm{mg} \mathrm{L}^{-1}\right)$.

dsDNA-modified electrode before interaction with 2AA is higher than the one obtained after interaction with 2-AA. Thus, any changes in the oxidation signals of the guanine and adenine were attributed to the interaction of 2-AA with the guanine and adenine (from the dsDNA that immobilized on the surface of dsDNAmodified SPE) as shown in figure 2. This decreasing trend could be explained as a possible damage or shielding of the oxidizable groups of guanine and adenine bases while 2-AA interacts with the dsDNA on SPE surface. Our obtained results showed that the modified electrode might be used for the direct detection of 2-AA interaction with dsDNA.

The dependence of 2-AA concentration on the guanine signal was studied, too. To perform this electrochemical study all current peaks were compared with the signal current obtained with the non-damaged guanine base (blank signal) (table 1 and figure 3 ). The results showed that guanine and adenine oxidation currents decreased with increasing concentration of 2-AA up to $20 \mathrm{mg} \mathrm{L}^{-1}$ and then they disappeared. Since the oxidation signal of guanine was more sensitive than adenine, the oxidation signal of guanine was considered for the next experiments. Different concentrations of 2-AA were analysed on the surface of this biosensor and percentage of decrease in guanine peak areas was calculated (table 1). The results are shown in figure 3 . As can be seen in the inset of figure 3, the oxidation signal of guanine gradually decreased, as the 2AA concentration increased and then reached a plateau after $20 \mathrm{mg} \mathrm{L}^{-1}$. This is due to the fact that the modified electrode surface was saturated by 2-AA in higher concentrations of the analyte. In order to evaluate the precision of this method a series of ten repetitive square wave
Table 1. Decreasing of guanine peak area after interaction with different concentration of 2-AA $(n=7)$.

\begin{tabular}{lccc}
\hline $\begin{array}{l}\text { Concentration } \\
(\mathrm{ppm})\end{array}$ & $\mathrm{GPA}_{\mathrm{b}}$ & $\mathrm{GPA}_{\mathrm{s}}$ & $\begin{array}{c}\text { Guanine damage } \\
(\mathrm{GD}, R \%)^{*}\end{array}$ \\
\hline 0.05 & 0.42 & 0.36 & $14.3( \pm 0.8)$ \\
0.08 & 0.42 & 0.32 & $23.8( \pm 0.4)$ \\
0.1 & 0.42 & 0.30 & $28.6( \pm 0.2)$ \\
0.5 & 0.42 & 0.23 & $45.2( \pm 0.5)$ \\
1 & 0.42 & 0.19 & $54.8( \pm 0.2)$ \\
2.5 & 0.42 & 0.13 & $69.0( \pm 0.2)$ \\
5 & 0.42 & 0.11 & $73.8( \pm 0.5)$ \\
10 & 0.42 & 0.07 & $83.3( \pm 0.9)$ \\
20 & 0.42 & 0 & $100.0( \pm 0.6)$ \\
\hline
\end{tabular}

$\mathrm{GPA}_{\mathrm{b}}$ : Guanine peak area after the interaction with the buffer solution.

$\mathrm{GPA}_{\mathrm{s}}$ : Guanine peak area after the interaction with the analyte.

$R \%:\left[\left(\mathrm{GPA}_{\mathrm{s}} / \mathrm{GPA}_{\mathrm{b}}\right)-1\right] \times 100$.

voltammetric measurements of the change in the oxidation peak current of guanine and adenine after those interactions with 2-AA concentration of 1 and $5 \mathrm{mg} \mathrm{L}^{-1}$ resulted in the relative standard deviations of $3.1 \%$ and $4.2 \%$, respectively.

\subsection{Analytical performance}

In order to evaluate the biosensor performance for analysis of 2-AA in real samples, commercial chlorine bleach and tap water were used for 2-AA analysis under the optimum condition.

3.4a SWV for possible interaction of dsDNA and chlorine at the dsDNA-modified electrode: Before evaluating the biosensor for analysis of 2-AA in tap water, the studies were carried out with bleach sample to evaluate the effect of different chlorine concentrations on dsDNA-modified SPE. In fact, water chlorination has been one of the major disease prevention treatments of this century and this is the process of adding chlorine or hypochlorite to water as a method of water purification to make it fit for human consumption as drinking water. In particular, chlorination is used to prevent the spread of waterborne diseases. Epidemiologic studies suggest an association between cancer in humans and consumption of chlorination by-products in drinking water. Thus, possible interaction of dsDNA and chlorine and the carcinogenic potential of chlorinated drinking water was investigated. For this reason chlorine bleach solution with different concentrations in the range from $10^{-4}\left(<0.05 \mathrm{mg} \mathrm{L}^{-1}\right)$ till $1 \% \mathrm{v} / \mathrm{v}(<500 \mathrm{mg}$ $\left.\mathrm{L}^{-1}\right)$ from the commercial chlorine bleach $(<5 \% \mathrm{w} / \mathrm{v})$ 


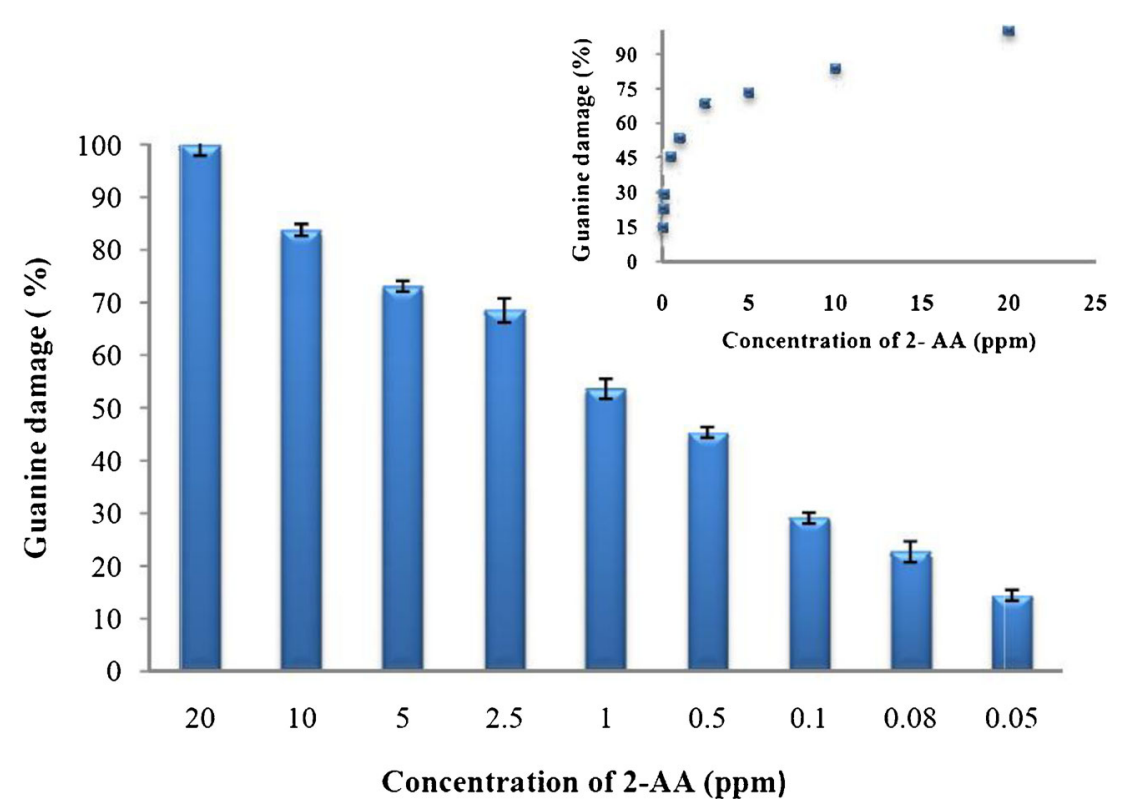

Figure 3. Effect of different concentrations of 2-AA on the signal of guanine immobilized on the SPE. Inset: Calibration curve for the determination of 2AA based on the changes of the oxidation signals of guanine after interaction with $0.05,0.08,0.1,0.5,1,2.5,5,10$ and $20 \mathrm{mg} \mathrm{L}^{-1}$ 2-AA on dsDNA-modified SPE (Error bars show the relative standard deviation, $n=7$ ).

with acetate buffer solution $(\mathrm{pH}=4.7, \mathrm{KCl} 0.1 \mathrm{~mol}$ $\mathrm{L}^{-1}$ ) were prepared to investigate the possible damage of dsDNA by chlorine. To prevent any error caused by decomposition of chlorine bleach, the solutions were prepared daily and used freshly.

Using the DNA biosensor, SWV was performed from 0.4 to $1.4 \mathrm{~V}$ and the results showed no changes in current sensitivities of guanine and adenine, compared to those without using the chlorine, while the concentration of chlorine was increased higher than $500 \mathrm{mg} \mathrm{L}^{-1}$ (figure 4). These results showed that the level of chlorine in tap water, swimming pool, etc. cannot make DNA damage and be considered in the carcinogenic and mutagenic groups.

\section{4b Investigation of chlorine effect in determination} of 2-AA: SWV oxidation signals of guanine and adenine at dsDNA-modified SPE, before and after interaction with $5 \mathrm{mg} \mathrm{L}^{-1}$ 2-AA on the electrode surface with acetate buffer solution $\left(\mathrm{pH}=4.7, \mathrm{KCl} 0.1 \mathrm{~mol} \mathrm{~L}^{-1}\right)$ are shown in figure $5 \mathrm{a}$ and $5 \mathrm{~b}$. Then, determination of 2-AA was carried on with the same condition in the presence of bleach solution containing $0.1 \%\left(<50 \mathrm{mg} \mathrm{L}^{-1}\right)$ chlorine $(0.01 \%$ chlorine is the maximum amount of chlorine in tap water and swimming pool). The obtained results showed no significant difference in the purine base signal (signal change $<5.0 \%$ ) while monitoring

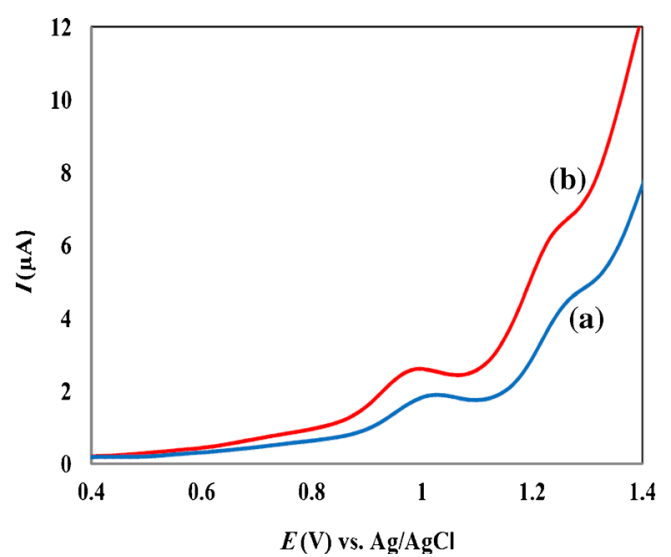

Figure 4. Effect of chlorine bleach $(0.1 \% v / v)$ sample on guanine and adenine oxidation signal in the presence of acetate buffer solution $\left(\mathrm{pH}=4.7, \mathrm{KCl} 0.1 \mathrm{~mol} \mathrm{~L}^{-1}\right)$. Oxidation signals of guanine and adenine obtained from dsDNAmodified electrode (a) in acetate buffer solution and (b) in the presence of chlorine bleach $(0.1 \% \mathrm{v} / \mathrm{v})$ sample.

2-AA compared to the one obtained without chlorine interference (figure 5c).

3.4c Analysis of 2-AA in the tap water sample: Under the optimum conditions, the proposed method was applied to the detection of 2-AA in the tap water sample, and the effect of possible interferences in the 


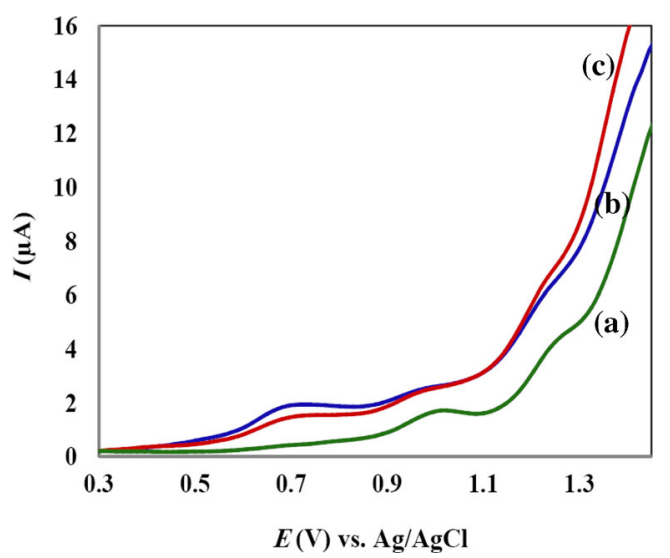

Figure 5. Square wave voltammogram of guanine and adenine obtained from dsDNA-modified electrode (a) in acetate buffer $\left(\mathrm{pH}=4.7, \mathrm{KCl} 0.1 \mathrm{~mol} \mathrm{~L}^{-1}\right)$, (b) after interaction with 2-AA $\left(5 \mathrm{mg} \mathrm{L}^{-1}\right)$ in acetate buffer solution, (c) after interaction with 2-AA $\left(5 \mathrm{mg} \mathrm{L}^{-1}\right)$ in the presence of chlorine bleach $(0.1 \% \mathrm{v} / \mathrm{v})$ sample in acetate buffer solution.

tap water to detect 2-AA was investigated. So, SWV oxidation signals of guanine and adenine at dsDNAmodified SPE, before and after interaction with $5 \mathrm{mg}$ $\mathrm{L}^{-1}$ 2-AA on the electrode surface with acetate buffer solution were carried out and the results are shown in figure $6 \mathrm{a}$ and $6 \mathrm{~b}$. Thereafter, determination of 2-AA was performed with the same condition in the tap water sample. As illustrated in figure $6 c$, no significant difference in the purine base signal (signal change $<5.0 \%$ ) to determine 2-AA in tap water compared to the one obtained in acetate buffer containing $5 \mathrm{mg} \mathrm{L}^{-1} 2-\mathrm{AA}$ was observed.

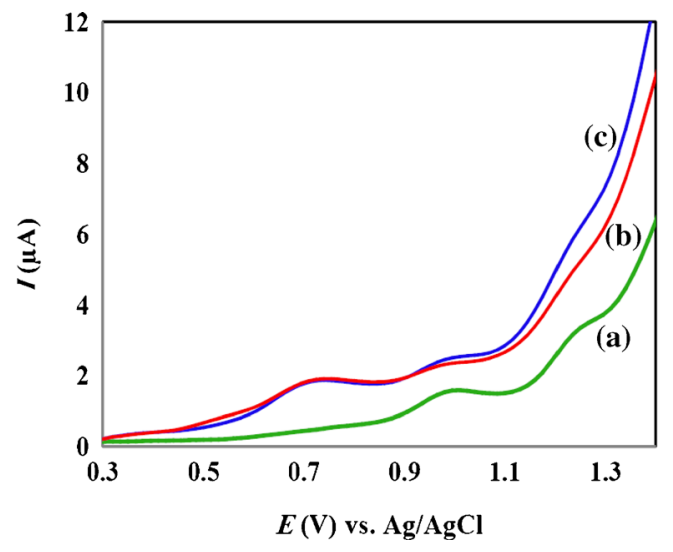

Figure 6. Square wave voltammogram of guanine and adenine obtained from dsDNA-modified electrode (a) in acetate buffer $\left(\mathrm{pH}=4.7, \mathrm{KCl} 0.1 \mathrm{~mol} \mathrm{~L}^{-1}\right)$, (b) after interaction with 2-AA ( $\left.5 \mathrm{mg} \mathrm{L}^{-1}\right)$ in acetate buffer solution, (c) after interaction with 2 -AA $\left(5 \mathrm{mg} \mathrm{L}^{-1}\right)$ in tap water sample in acetate buffer.

\section{Conclusions}

A low-cost screen-printed DNA biosensor was developed in this study as a simple strategy to quantitatively screen 2-AA. The natural electrochemistry of guanine and adenine bases were exploited to develop a DNA-based biosensor for the assessment of 2-AA in bleach and water samples. The interaction of 2-AA with dsDNA was characterised by voltammetric methods. As a result of the interaction between 2-AA in different concentrations with dsDNA, a decreasing trend of the response based on the signals of guanine and adenine was observed. The results demonstrated that the DNA/2-AA could be used as a biosensor not only to explore the interaction of the dsDNA with 2-AA, but also to detect DNA damage caused by 2-AA. The interaction of electroactive and non-electroactive agents with DNA can be monitored by using the procedure reported here. The intrinsic signals of DNA give an idea about the behaviour of the agent towards DNA. Detecting the voltammetric behaviour of several carcinogenic compounds that interact with DNA would be valuable in the design of sequence-specific DNA binding molecules for application in chemotherapy and in the development of biotechnological tools for the pointof-care tests based on DNA. The results obtained for the 2-AA oxidation using dsDNA biosensor demonstrates a good possibility for developing an electroanalytical methodology for 2-AA detection. The fabrication of a DNA-based electrochemical biosensor is critically dependent on the selection of an immobilization procedure like physisorption, covalent binding, electrochemical adsorption, or electrochemical entrapment. The electrochemical adsorption method has been used to immobilize calf thymus dsDNA onto disposable carbon screen printed electrodes.

\section{Supplementary Information}

The electronic supporting information can be seen at www.ias.ac.in/chemsci.

\section{References}

1. Kozurkova M, Sabolova D, Paulıkova H, Janovec L, Kristian P, Bajdichova M, Busa J, Podhradsky D and Imrich J 2007 Int. J. Biol. Macromol. 41415

2. Palecek E 1960 Nature 188656

3. Palecek E, Scheller F and Wang J 2005 Electrochemistry of Nucleic Acids and Proteins. Towards Electrochemical Sensors for Genomics and Proteomics (London: Elsevier) 
4. Prabhakar N, Arora K, Singh S P, Singh H and Malhotra B D 2007 Anal. Biochem. 36671

5. Ensafi A A, Rezaei B, Amini M and Heydari-Bafrooei E 2012 Talanta $\mathbf{8 8} 244$

6. Meric B, Kerman K, Ozkan D, Kara P, Erdem A, Kucukoglu O, Erciyas E and Ozsoz M 2002 J.Pharm. Biomed. Anal. 301339

7. Oliveira-Brett A M 2008 Bioelectrochemistry: Fundamentals, Experimental Techniques and Applications, Bartlett P (ed.) (Chichester: John Wiley \& Sons)

8. Dogan-Topal B and Ozkan S A 2011 Talanta 8780

9. Mirmomtaz E, Ensafi A A and Soleimanian-Zad S 2009 Electrochim. Acta $\mathbf{5 4} 1141$

10. Xia C, Guoli S, Jianhui J and Ruqin Y 1999 Anal. Lett. 32717

11. Chaires J B 1998 Curr. Opin. Struct. Biol. 8314

12. Egorin M J 1998 Cancer Chemother. Pharmacol. 42 S22

13. Fritzsche H, Akhebat A, Taillandier E, Rippe $\mathrm{K}$ and Jovin T M 1993 Nucleic Acids Res. 215085

14. Nunn C M, Meervelt L V and Zhang S 1991 J. Mol. Biol. 222167

15. Feng Q, Li N Q and Jiang Y Y 1997 Anal. Chim. Acta 34497

16. Mirmomtaz E and Ensafi A A 2009 Electrochim. Acta 544353

17. Yardım Y, Keskin E, Levent A, Ozsoz M and Senturk Z 2010 Talanta 801347

18. McGown L B, Joseph M, Pitner J, Vonk G and Linn C 1995 Anal. Chem. 67 663A

19. Fatima Barroso M, Delerue-Matos $\mathrm{C}$ and Oliveira M B P P 2012 Food Chem. 1321055

20. Marco M P and Barcelo D 1996 Meas. Sci. Technol. 7 1547

21. Mount D I and Anderson-Carnahan L 1988 Methods for Aquatic Identification Evaluations, EPA/600/3-88/034 (Duluth: US Environmental Protection Agency)

22. Sarakinos H C, Bermingham N, White P A and Rasmussen J B 2000 Environ. Toxicol. Chem. 1963

23. Zhang Q, Crittenden J C and Mihelcic J R 2001 Environ. Sci. Technol. 351282

24. Freitas dos Santos L, Defrenne L and Krebs-Brown A 2002 Anal. Chim. Acta 45641
25. Gomot de Valfleury A and Bispo A 2000 Environ. Sci. Technol. 341865

26. Monica Tencaliec A, Laschi S, Magearu V and Mascini M 2006 Talanta 69365

27. Marrazza G, Chianella I and Mascini M 1999 Anal. Chim. Acta 387297

28. Chiti G, Marrazza G and Mascini M 2001 Anal. Chim. Acta 427155

29. Mascini M, Palchetti I and Marrazza G 2001 Fresenius J. Anal. Chem. 36915

30. Wang J, Rivas G, Cai X, Palecek E, Nielsen P, Shirashi H, Dontha N, Luo D, Parrado C, Chicarro M, Farias P A M, Valera F S, Grant D H, Ozsoz M and Flair M N 1997 Anal. Chim. Acta 3471

31. Fojta M and Palecek E 1997 Anal. Chim. Acta 3421

32. Fojta M, Stankova V, Palecek E, Koscielniak P and Mitas J 1998 Talanta 46155

33. Palecek E and Fojta M 2001 Anal. Chem. 73 74A

34. Ahn J, Hwang E, Youn C, Banu D L, Kimc B, Niazi J H and Gu M 2009 Biosens. Bioelectron. 25767

35. Wang J, Ozsoz M, Cai X, Rivas G, Shirashi H, Grant D H, Chicharro M, Fernandes J and Palecek E 1998 Bioelectrochem. Bioenerg. 4533

36. Hashimoto K, Ito K and Ishimori Y 1994 Anal. Chim. Acta 286219

37. Palanti S, Marrazza G and Mascini M 1996 Anal. Lett. 292309

38. Gato W E and Means J C 2011 Am. J. Biochem. Mol. Biol. 1275

39. Abreu F C, Goulart M O F and Oliveira Brett A M 2002 Biosens. Bioelectron. 17913

40. Cagnini A, Palchetti I, Lionti I, Mascini M and Turner A P F 1995 Sens. Actuators B 2485

41. Wang J, Cai X, Wang J and Jonsson C 1995 Anal. Chem. 674065

42. Wang J, Cai X, Jonsson C and Balakrishnan M 1996 Electroanalysis $\mathbf{8} 20$

43. Rice M E, Galus Z and Adams R N 1983 J. Electroanal. Chem. 14389

44. Palecek E 1996 Electroanalysis 87

45. Du M, Xiaogang H, Zihao Z and Shouguo W 2007 Food Chem. 105883 